\title{
EFFECTS OF CALCIUM, AVAILABLE PHOSPHORUS AND SODIUM DI- FORMATE LEVELS: 1- PERFORMANCE AND TIBIA MEASUREMENTS OF BROILER CHICKS
}

\author{
S.A. Ibrahim, H.A. El Alaily; M.A.M. Abdelaziz; A.Y.M. Abdelhady and A.I. El-Faham \\ Poultry Production Department, Faculty of Agriculture, Ain Shams University, Egypt
}

\section{SUMMARY}

\begin{abstract}
A $\mathrm{n}$ experiment was conducted to determine the effect of adding different sodium di-format (NDF) levels in the presence of low levels calcium and available phosphorus diets on broiler productive performance and tibia measurements. A total number of 140 one day old Hubbard broiler chicks were classified into 7 equal groups, each was subdivided into 4 replicates with 5 chicks. The control group was fed standard (starter and grower) diets formulated ensuring sufficient supply of nutrients suggested by the guidebook of Hubbard broilers that contain $100 \%$ (Ca and AP) requirements without (NDF) and a $3 \times 2$ factorial arrangement with 3 different levels of $\mathrm{Ca} \& \mathrm{AP}$ being $(50 \%, 40 \%$ and $30 \%)$ from requirements and 2 levels of dietary NDF (1.5 and $2.25 \mathrm{~kg} / \mathrm{ton})$. Feed and water were supplied ad-libitum throughout the whole experiment which lasted till 35 days of age. The results indicated that: Under the condition of the present study, broiler chicks fed control diets or diets containing $50 \%$, Ca \& AP with $2.25 \mathrm{~kg} / \mathrm{ton}$ (T4) improved productive performance (live body weight, body weight gain, feed consumption and feed conversion ratio) comparable or better than other treatments. Similar trends were observed regarding the effect of previous dietary treatments on tibia bone measurements (Tibia; length and width) and tibia chemical composition (tibia $\mathrm{Ca} \& \mathrm{P}$ ) percentages. However, broiler chicks fed (T4) diets during experimental period (35 days) reflected the lowest significant tibia breaking strength and ash\% compared with those fed control diets It is obvious that, the best performance was seen when $50 \% \mathrm{Ca} \& \mathrm{AP} 2.25$ $\mathrm{kg} / \mathrm{ton}(\mathrm{NDF})$ were applied in broiler diets without any adverse effect on productive performance and most of tibia measurements and chemical composition.
\end{abstract}

Keywords: Calcium, Phosphorus, Sodium diformate, Productive performance and tibia measurements.

\section{INTRODUCTION}

Calcium and phosphorous are couple of essential inorganic materials which are involved in many physiological functions of the body of living poultry (Underwood and Suttle, 2001).

The Ca/AP ratio of 2.2 was found to be optimal for P efficiency (Van der Klis and Gerritsen, 1994), whereas the $\mathrm{Ca} / \mathrm{AP}$ ratio should range between 1.5 and 2.2 (Dieckmann, 2004). Moreover, The P utilization is affected by many factors, such as the amount of $\mathrm{P}$ in the feed (Günther et al., 1978), the age of the animal and sources of P supply (Günther and Al-Masri, 1988), the amounts of P, Ca and the Ca: AP ratio in the feed (Hermes, 1977) and phytase activity (Schoner et al., 1993) in addition to organic acids supply. It was hypothesized that a high Ca:AP ratio combined with a marginal AP level would be harmful for bone development of broilers. However, low $\mathrm{Ca} / \mathrm{AP}$ ratio might obstruct bone formation because of a $\mathrm{Ca}$ deficiency. However, Deficiencies of calcium and phosphorus lead to their reduction in bone (Wilson and Duff, 1991; Hemme et al., 2005).

Summers (1997) declared that dietary P levels could be reduced by up to $20 \%$ for most classes of poultry without any adverse effect on bird's performance. Low levels of Ca and NPP can be fed up to the finisher phase without retarding performance (Dhandu and Angel, 2003). Concerning water consumption, birds fed deficient $\mathrm{Ca}$ increase feed and water intake in comparison to those getting sufficient dietary Ca (Damron and Flunker, 1995). In addition, many experiments have reported that dietary organic acids and their salts can increase phosphorus utilization in corn-soybean meal diets fed to broiler chickens (Esmaeilipour et al., 2011) 


\section{Ibrahim et al.}

The P utilization may be increased due to the chelating properties of organic acids with calcium, which can result in increased phytate-phosphorus solubility, increasing their ability to be hydrolyzed (Centeno et al., 2007).

A new molecule (sodium diformate, similar to potassium diformate) has been proven to be effective against pathogenic bacteria, including salmonella, along the whole gastro-intestinal tract (Hebeler et al., 2000). The reduced impact of pathogenic bacteria on the broiler, as well as the improved gut microflora, leading to a state of eubiosis in treated chickens, suggests that including diformate in broiler diets will also result in improved bird performance. Several trials have been also being carried out over the last half-decade world-wide that document positive effects on broiler performance.

The study by (García et al., 2007; Lückstädt and Wegletner, 2012; Abdelhady et al., 2015) analyzed the average impact from all studies on the effect of the additive sodium diformate on the performance parameters weight gain, feed efficiency, mortality and productive productivity. The final data-set contained the results of 8 documented studies, comprising 17 trials with sodium diformate (NDF) inclusion, which ranged from $0.1 \%$ to $0.6 \%$. Results are expressed as percentage difference from the negative control. The average level of dietary NDF from the data-set in all treated broilers was $0.28 \%$. Only a numerical increase of feed intake $(1.1 \%)$ could be monitored $(\mathrm{P}=0.22)$. However, the performance of broilers based on daily gain was significantly increased by $5.2 \%(\mathrm{P}<0.001)$. Furthermore, the FCR was also significantly improved $(4.1 \%$; $\mathrm{P}<0.01)$. Survival was increased on average by $2.3 \%(\mathrm{P}<0.05)$. Finally, the European Broiler Index (EBI) improved significantly due to the inclusion of NDF by $12.4 \%(\mathrm{P}<0.001)$. It is therefore concluded that dietary sodium diformate can improve broiler production world-wide (Lückstädt et al., 2014). Moreover, Boling et al. (2000a) reported that increasing level of citric acid up to $6 \%$ linearly increased percent tibia ash from $26.9 \%$ (P-deficient basal diet) to 38.6\%. Suggested that citric acid chelated $\mathrm{Ca}$ in the diet and prevent the formation of $\mathrm{Ca}$ phytate complexes and therefore increased phytate $\mathrm{P}$ utilization with a difference in the response of broilers vs. laying hens to citric acid.

Accordingly, the current study aimed to investigate effects of three dietary Ca and NPP deficiency levels with constant $\mathrm{Ca}$ : AP ratios, with two levels of NDF addition as a feed additive in broiler diets, on productive performance and tibia bone characteristic.

\section{MATERIALS AND METHODS}

The current study was carried out at the Poultry Nutrition Farm, Poultry Production Department, Faculty of Agriculture, Ain Shams University, Qalyubia, Egypt, in order to investigate the role of adaptive non-phytate phosphorus deficiency with sodium diformate (NDF) supplementation on performance and tibia measurements of broilers. A total number of 140 one day old Hubbard broiler chicks were divided into 7 equal treatments groups, each included 4 replicates with 5 chicks each. Experimental treatments consisted of control group plus $3 \times 2$ factorial arrangement with 3 different levels of $\mathrm{Ca} \times \mathrm{AP}$ being $(50 \%, 40 \%$ and $30 \%)$ from requirements and 2 levels of dietary sodium diformate (NDF) 1.5 and $2.25 \mathrm{~kg} / \mathrm{ton}$ ), respectively. As presented in Table (1) control diets were formulated ensuring sufficient supply of nutrients suggested by the guidebook of Hubbard broiler that contain 100\% $\mathrm{Ca} \&$ AP requirements without (NDF). Chicks were reared in battery cages and, were fed starter diets from 1 to 14 days of age while, grower diets were fed from 15 to 35 days of age.

Chicks of all experiments were kept under similar hygienic and vaccinated against common diseases. The performance parameters included body weight and feed consumption which were determined weekly and taken body weight gain (BWG), feed conversion ratio (FCR) and performance index were calculated slaughtered then the six tibiae were removed, numbered and frozen at $-20^{\circ}$, fat and muscle tissues along with cartilage caps were removed prior to storage. Tibia weight $(\mathrm{g})$, was determined to by using a three decimal digital scale, tibia length and width were determined using a digital micrometer according to the methods described by Samejina (1990).

Tibia breaking strength (TBS) was determined using the method prescribed by Fleming et al. (1998). Proximate chemical analysis of bone was determined by using standard (AOAC, 1995).

Statistical procedures: The collected data were subjected to two way analysis of variance to detected the effects of $\mathrm{Ca} \& \mathrm{AP}$ levels (L) and NDF levels (E) and their interactions ( $\mathrm{L} * \mathrm{E})$ using the general liner 
model (GLM) procedure of SAS (SAS 2002) according to the following model :

Tijk = trait measured, $\mathrm{M}=$ Overall mean, $\mathrm{Li}=\mathrm{Ca} \& \mathrm{AP}$ levels, $\mathrm{i}=(1,2,3)$

$\mathrm{Ej}=\mathrm{NDF}$ levels, $\mathrm{j}=(1,2),(\mathrm{L} * \mathrm{~J}) \mathrm{ij}=$ Interaction between Ca \& AP levels and NDF levels.

Eijk $=$ Experimental error

When significant differences among means were found, means were separated using Duncan's multiple range tests (Duncan, 1955).

Table (1): Feed ingredients and chemical composition of diets (starter period).

\begin{tabular}{|c|c|c|c|c|c|c|c|}
\hline Ingredient & Control & $\mathrm{T} 1$ & $\mathrm{~T} 2$ & T3 & $\mathrm{T} 4$ & T5 & T6 \\
\hline Yellow Corn & 52.76 & 55.390 & 55.81 & 56.15 & 55.315 & 55.735 & 56.075 \\
\hline Soy bean meal $44 \%$ & 30.80 & 31.75 & 31.75 & 32.50 & 31.75 & 31.75 & 32.50 \\
\hline Corn Gluten $60 \%$ & 9.00 & 8.00 & 8.00 & 7.50 & 8.00 & 8.00 & 7.50 \\
\hline Vegetable Oil & 2.57 & 2.00 & 2.00 & 1.85 & 2.00 & 2.00 & 1.85 \\
\hline Ca Carbonate & 1.80 & 0.85 & 0.66 & 0.48 & 0.85 & 0.66 & 0.48 \\
\hline $\mathrm{MCaP}^{*}$ & 1.82 & 0.63 & 0.40 & 0.15 & 0.63 & 0.40 & 0.15 \\
\hline $\mathrm{HCl}$ Lysine & 0.34 & 0.32 & 0.32 & 0.30 & 0.32 & 0.32 & 0.30 \\
\hline MHA-METH*** & 0.21 & 0.21 & 0.21 & 0.22 & 0.21 & 0.21 & 0.22 \\
\hline Salt $(\mathrm{NaCl})$ & 0.30 & 0.30 & 0.30 & 0.30 & 0.30 & 0.30 & 0.30 \\
\hline Anti-mycotoxins $* * *$ & 0.10 & 0.10 & 0.10 & 0.10 & 0.10 & 0.10 & 0.10 \\
\hline Sodium diformate (NDF) & 0.00 & 0.15 & 0.15 & 0.15 & 0.225 & 0.225 & 0.225 \\
\hline Premix $* * * *$ & 0.30 & 0.30 & 0.30 & 0.30 & 0.30 & 0.30 & 0.30 \\
\hline Total & 100.00 & 100.00 & 100.00 & 100.00 & 100.00 & 100.00 & 100.0 \\
\hline \multicolumn{8}{|c|}{ Chemical Composition (Calculated) \# } \\
\hline $\mathrm{CP} \%$ & 23.01 & 23.02 & 23.02 & 23.03 & 23.05 & 23.01 & 23.00 \\
\hline $\mathrm{ME} \mathrm{Kcal/Kg}$ & 3004 & 3009 & 3005 & 3011 & 3008 & 3015 & 3010 \\
\hline $\mathrm{Ca} \%$ & 1.00 & 0.50 & 0.40 & 0.30 & 0.50 & 0.40 & 0.30 \\
\hline $\mathrm{AP} \%$ & 0.50 & 0.25 & 0.20 & 0.15 & 0.25 & 0.20 & 0.15 \\
\hline \multicolumn{8}{|c|}{ Grower diet (15-35 days) } \\
\hline Ingredients & Control & $\mathrm{T} 1$ & $\mathrm{~T} 2$ & $\mathrm{~T} 3$ & $\mathrm{~T} 4$ & T5 & T6 \\
\hline Yellow Corn & 55.08 & 57.37 & 57.76 & 58.91 & 57.295 & 57.685 & 58.835 \\
\hline Soy bean meal $44 \%$ & 30.00 & 31.00 & 31.00 & 30.70 & 31.00 & 31.00 & 30.70 \\
\hline Corn Gluten $60 \%$ & 6.00 & 5.00 & 5.00 & 5.00 & 5.00 & 5.00 & 5.00 \\
\hline Vegetable Oil & 4.50 & 4.00 & 4.00 & 3.50 & 4.00 & 4.00 & 3.50 \\
\hline Ca Carbonate & 1.60 & 0.77 & 0.59 & 0.42 & 0.77 & 0.59 & 0.42 \\
\hline Mono CaP* & 1.62 & 0.52 & 0.32 & 0.13 & 0.52 & 0.32 & 0.13 \\
\hline $\mathrm{HCl}$ Lysine & 0.24 & 0.22 & 0.21 & 0.22 & 0.22 & 0.21 & 0.22 \\
\hline MHA -METH & 0.26 & 0.27 & 0.27 & 0.27 & 0.27 & 0.27 & 0.27 \\
\hline Salt $(\mathrm{NaCl})$ & 0.30 & 0.30 & 0.30 & 0.30 & 0.30 & 0.30 & 0.30 \\
\hline Anti-mycotoxins $* * *$ & 0.10 & 0.10 & 0.10 & 0.10 & 0.10 & 0.10 & 0.10 \\
\hline Formi NDF & 0.00 & 0.15 & 0.15 & 0.15 & 0.225 & 0.225 & 0.225 \\
\hline Premix $* * * * *$ & 0.30 & 0.30 & 0.30 & 0.30 & 0.30 & 0.30 & 0.30 \\
\hline Total & 100.00 & 100.00 & 100.00 & 100.00 & 100.00 & 100.0 & 100.00 \\
\hline \multicolumn{8}{|c|}{ Chemical Composition (Calculated) \# } \\
\hline $\mathrm{CP} \%$ & 21.04 & 21.06 & 21.05 & 21.08 & 21.03 & 21.02 & 21.07 \\
\hline $\mathrm{ME} \mathrm{Kcal/Kg}$ & 3111 & 3109 & 3125 & 3118 & 3105 & 3110 & 3105 \\
\hline $\mathrm{Ca} \%$ & 0.90 & 0.45 & 0.36 & 0.27 & 0.45 & 0.36 & 0.27 \\
\hline $\mathrm{AP} \%$ & 0.45 & 0.225 & 0.18 & 0.14 & 0.225 & 0.18 & 0.14 \\
\hline
\end{tabular}




\section{Ibrahim et al.}

\section{RESULTS AND DISCUSSION}

\section{Production performance}

Productive performance traits of broilers from one to 35 days of age in response to dietary different levels of $\mathrm{Ca} \& \mathrm{AP}$ and NDF are presented in Table (2). The obtained data showed that there were significant differences in LBW and BWG values among treatments during whole experimental period (1-35days) responses of chicks fed diets containing different levels of (Ca \& AP) showed that chicks fed diets containing high levels of (Ca \& AP), $100 \%$ and 5\%, supported the highest LBW and BWG compared with those fed the two other levels (40\% and 30\%). The corresponding figures were 1628 and $1569 \mathrm{~g}$ versus 1489 and $1416 \mathrm{~g}$ respectively for LBW, 1586 and $1527 \mathrm{~g}$ versus 1447 and $1376 \mathrm{~g}$ respectively for BWG with significant differences between treatments. Levels of NDF showed the same trend since the higher LBW and BWG were detected for the chicks fed $2.25 \mathrm{~kg} /$ ton NDF diets compared with chicks fed $1.50 \mathrm{~kg} / \mathrm{ton}$ NDF diets and the corresponding figures were 1582 and $1540 \mathrm{~g}$ versus 1395 and $1355 \mathrm{~g}$ respectively with significant differences between the two treatments. In addition, feeding (T4) diets showed the highest LBW $(1634 \mathrm{~g})$ and BWG (1592) followed by those fed control diets being $1628 \mathrm{~g}$ and $1586 \mathrm{~g}$, respectively. Besides, the differences between the two treatments were insignificant.

These results might be justified by several reasons; First: Formi NDF might inhibit intestinal bacteria that competing with the host for available nutrients, and a reduction of possibly toxic bacterial metabolites, thus improving LBW and BWG of chicks. Second, lower ilium pH might increase nutrient availability.

Data of broiler body weight, body weight gain, from both experiments were commonly, in agreement with the results of (Bozkurt et al., 2009). Other authors reported that formic acid $(0.1$ and $1.0 \%)$ had positive effects on growth performance of broilers (Helen and Christian, 2010). While, Hernadez et al. (2006) reported that formic acid ( 0.5 to $1 \mathrm{~kg} /$ ton) did not affect LBW and BWG of broilers that may be due to low levels of acids non-sufficient to cause performance improvement.

\section{Feed consumption (FC) and feed conversion ratio (FCR)}

Data presented in Table (2) indicated that FC per chick (gram/chick) was significantly decreased by feeding low Ca \& AP level (30\%) compared with those fed other treatments (100, 50 or 40\%).

The corresponding figures were 231 gversus 2570,2536 and $2429 \mathrm{~g}$ with significant differences between

Table (2). Effect of different dietary treatments on growth performance of broiler chicks.

\begin{tabular}{|c|c|c|c|c|c|c|c|}
\hline & \multirow{2}{*}{ Treatment } & \multicolumn{2}{|c|}{ LBW } & \multirow{2}{*}{ BWG } & \multirow{2}{*}{$\mathrm{FC}$} & \multirow{2}{*}{ FCR } & \multirow{2}{*}{ PI } \\
\hline & & 1 day & 35 days & & & & \\
\hline \multirow{4}{*}{ 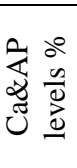 } & 100 & 41.75 & $1628 \mathrm{a}$ & $1586 a$ & $2570^{\mathrm{a}}$ & 1.62 & $100.49 a$ \\
\hline & 50 & 41.40 & $1565 b$ & $1523 a$ & $2506 a$ & 1.65 & $94.85 \mathrm{a}$ \\
\hline & 40 & 41.48 & $1484 \mathrm{c}$ & $1442 b$ & $2406 \mathrm{ab}$ & 1.67 & $88.86 b$ \\
\hline & 30 & 39.74 & $1419 \mathrm{c}$ & $1379 \mathrm{c}$ & $2305 b$ & 1.67 & $84.97 b$ \\
\hline \multirow{3}{*}{ 它 } & 0.00 & 41.75 & $1628 \mathrm{a}$ & $1586 a$ & $2570 \mathrm{a}$ & $1.62 b$ & 100.49 \\
\hline & 1.50 & 39.97 & $1395 b$ & $1355 b$ & $2213 b$ & $1.63 b$ & 85.58 \\
\hline & 2.25 & 41.77 & $1583 a$ & $1541 \mathrm{a}$ & $2598 \mathrm{a}$ & $1.69 \mathrm{a}$ & 93.67 \\
\hline \multirow{7}{*}{ 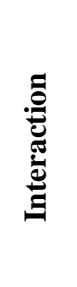 } & CONTROL & 41.75 & $1628 \mathrm{a}$ & $1586 a$ & $2570 \mathrm{a}$ & 1.62 & $100.49 a$ \\
\hline & $\mathrm{T} 1$ & 40.65 & $1495 \mathrm{c}$ & $1454 \mathrm{~b}$ & $2385 b$ & 1.64 & $91.16 \mathrm{ab}$ \\
\hline & $\mathrm{T} 2$ & 39.6 & $1393 d$ & $1353 \mathrm{c}$ & $2179 \mathrm{c}$ & 1.61 & $86.52 b$ \\
\hline & $\mathrm{T} 3$ & 39.65 & $1297 \mathrm{e}$ & $1257 d$ & $2075 d$ & 1.65 & $78.61 b$ \\
\hline & $\mathrm{T} 4$ & 42.15 & $1634 a$ & $1592 \mathrm{a}$ & $2627 a$ & 1.65 & $99.03 \mathrm{a}$ \\
\hline & $\mathrm{T} 5$ & 43.35 & $1574 \mathrm{ab}$ & $1531 \mathrm{ab}$ & $2633 \mathrm{ab}$ & 1.72 & $91.51 \mathrm{a}$ \\
\hline & T6 & 39.82 & $1540 \mathrm{~b}$ & $1500 \mathrm{ab}$ & $2535 a$ & 1.69 & $91.12 \mathrm{ab}$ \\
\hline \multirow{3}{*}{$\dot{\mathscr{S}}$} & $\mathrm{Ca} \& \mathrm{AP}$ & NS & $* *$ & $* *$ & $*$ & NS & $*$ \\
\hline & NDF & NS & $* *$ & $* *$ & $* *$ & $*$ & NS \\
\hline & INTERACTION & NS & $* *$ & $*$ & $*$ & NS & $*$ \\
\hline
\end{tabular}

$a^{\prime} b c$, d Means within the same column with different superscripts are significantly different.

Sig. = Significance $* *(P<0.01), *(P<0.05) . N S=$ Non-Significant .

$L B W=$ live body weight, $B W G=$ Body weight gain, $F C=$ feed consumption, $F C R=$ feed conversion ratio 
treatments. In the same order during whole experimental period, chicks fed diet containing low level o NDF $(1.50 \mathrm{~kg} / \mathrm{ton})$ significantly decreased FC compared with that fed high level of NDF $(2.25 \mathrm{~kg} / \mathrm{ton})$, the corresponding figures were 2213 versus $2598 \mathrm{~g}$ with significant differences between treatments. In addition, FC per chick decreased by feed T1-3 diets compared with those fed control or T4-6 diets, with significant differences feed conversion ratio (FCR), the figures of FCR indicated insignificant differences between chicks fed different levels of $\mathrm{Ca} \& \mathrm{AP}$.

The best FCR was detected for the chicks fed control diets (100\%) being (1.62) compared to other dietary treatments 50,40 or $30 \%$ (being, 1.66, 1.67 and 1.68 respectively), however, the differences failed to be significant. In the same order, the worst FCR was detected for the chicks fed diets incorporated with (1.50 $\mathrm{kg} / \mathrm{ton}) \mathrm{NDF}$ compared with chicks fed higher level of NDF $(2.25 \mathrm{~kg} / \mathrm{ton})$, the corresponding figures were 1.68 versus 1.63 respectively. Besides the differences between the two treatments were significant. Moreover, the figures of FCR indicated insignificant differences between chicks fed diets containing low levels of Ca \& AP with different levels of NDF (T1-6) compared with those fed control diet. The least FCR was detected for the chicks fed T2 (1.61) or control (1.62) diets. On the other hand, the worst FCR were found in chicks fed T6 (1.69) or T5 (1.71) diets and differences between treatments failed to be significant (Table 2).

Increased feed intake in (control), (T4), (T5) and (T6) groups could be explained by three reasons. First, broilers fed diet with low $\mathrm{Ca}$ and $\mathrm{P}$ showed maximized FC and poorer FCR in a try to manage LBW according to Waldroup et al. (2000) and Rouhollah et al., (2010).

Second, birds might adapt to sufficient $\mathrm{Ca}$ and $\mathrm{P}$ by raising FC that caused worse FCR as Kheiri and Rahmani (2006) who suggested that using low levels of both $\mathrm{Ca}$ and $\mathrm{P}$ up to $30 \%$ of requirement suggested levels, would affect FCR negatively. Third reason, Formi NDF supplementation might increase FC that raised FCR. This was in accordance with Adil et al. (2011) who stated that addition of $2 \%$ formic acid, showed significantly $(\mathrm{p}<0.05)$ higher body weight gains and feed conversion ratio Hernadez et al. (2006); Helen and Christian (2010).

\section{Tibia measurements:}

The results in Table (3) show the relationship between dietary treatments and some tibia measurements and tibia breaking strength (TBS). The percentages of tibia weight in relation to LBW for broiler chickens fed control diets reflected insignificant differences than those fed different dietary treatments (T1-6). On the same order, tibia length $(\mathrm{cm})$ and tibia width $(\mathrm{mm})$ were almost the same when chickens fed control or T1-6 diets. The response to feeding low levels of Ca \& AP with different levels of NDF on tibia measurement showed insignificant differences without clear trend in the relation to the levels of Ca \& AP or levels of NDF.

In general, the figures of tibia measurement were seen when $30 \% \mathrm{Ca} \& \mathrm{AP}$ with $2.25 \mathrm{~kg} \mathrm{NDF} / \mathrm{ton}$ (T6) was incorporated in diets the corresponding values were $1.00 \%, 10.43 \mathrm{~cm}$ and $2.53 \mathrm{~mm}$ for tibia weight $\%$, tibia length and tibia width respectively. Chemical composition of tibia bone for broiler chick as affected by experimental treatments is illustrated in Table (3). The obtained data showed that there were significant differences in Tibia (Ash, $\mathrm{Ca}$ and $\mathrm{P}$ ) percentages among treatments. Birds fed control diets reflected the highest figures compared with other treatments (T1-6).

However, Ash \% decreased by $(22.47 \%, 22.31 \%$ and $31.13 \%)$ for chicks fed $(50 \%, 40 \%$ and $30 \%)$ Ca \& AP levels diets compared with those feed control diets and Tibia (Ca and P) percentages showed similar trend. Besides, the differences between treatments were significant. Moreover, feeding diets containing 2.25 $\mathrm{kg} / \mathrm{ton}(\mathrm{NDF})$ gave the highest Ash \% (37.03 vs. 34.96), Ca\% (13.52 vs, 13.23) and P\% (8.96vs, 8.32) compared the diets containing $1.52 \mathrm{~kg} / \mathrm{ton}$ (NDF), however, the differences failed to be significant except ash \%. In the same order, dietary NDF levels with different Ca \& AP levels showed that control, T1, T2, T4 and T5 groups appeared significantly $(\mathrm{P}>0.05)$ similar and higher than other treatments $\mathrm{T} 3$ an $\mathrm{T} 6$, except ash\%. On the other hand, data showed that chicks fed control diets had highest values and chicks fed (T3) had the lowest values of ash, $\mathrm{Ca}$ and $\mathrm{P}$ percentages. Besides, the differences between the two treatments were significant. In accordance with Yan et al. (2001) who indicated that birds fed control diet had higher ash weight of $\mathrm{P}$ or $\mathrm{Ca}$ consumed at all ages as compared with that of birds fed the deficient $\mathrm{Ca}$ and $\mathrm{P}$ treatments, this could be attributed to considerable adaptation to $\mathrm{P}$ and $\mathrm{Ca}$ restriction in deficient $\mathrm{Ca}$ and $\mathrm{P}$ treatments. And bond mineral content of birds at control treatments had higher values. Additionally, RafaczLivingston et al. (2005) employed that citric acid to improve P utilization as well as tibia Ca \& P content and 


\section{Ibrahim et al.}

enhanced bone strength in broilers by improving total digestibility of Ca and P (Snow et al., 2004 and Islam, 2012).

Table (3) Effect of different dietary treatments on tibia measurements of broiler chicks.

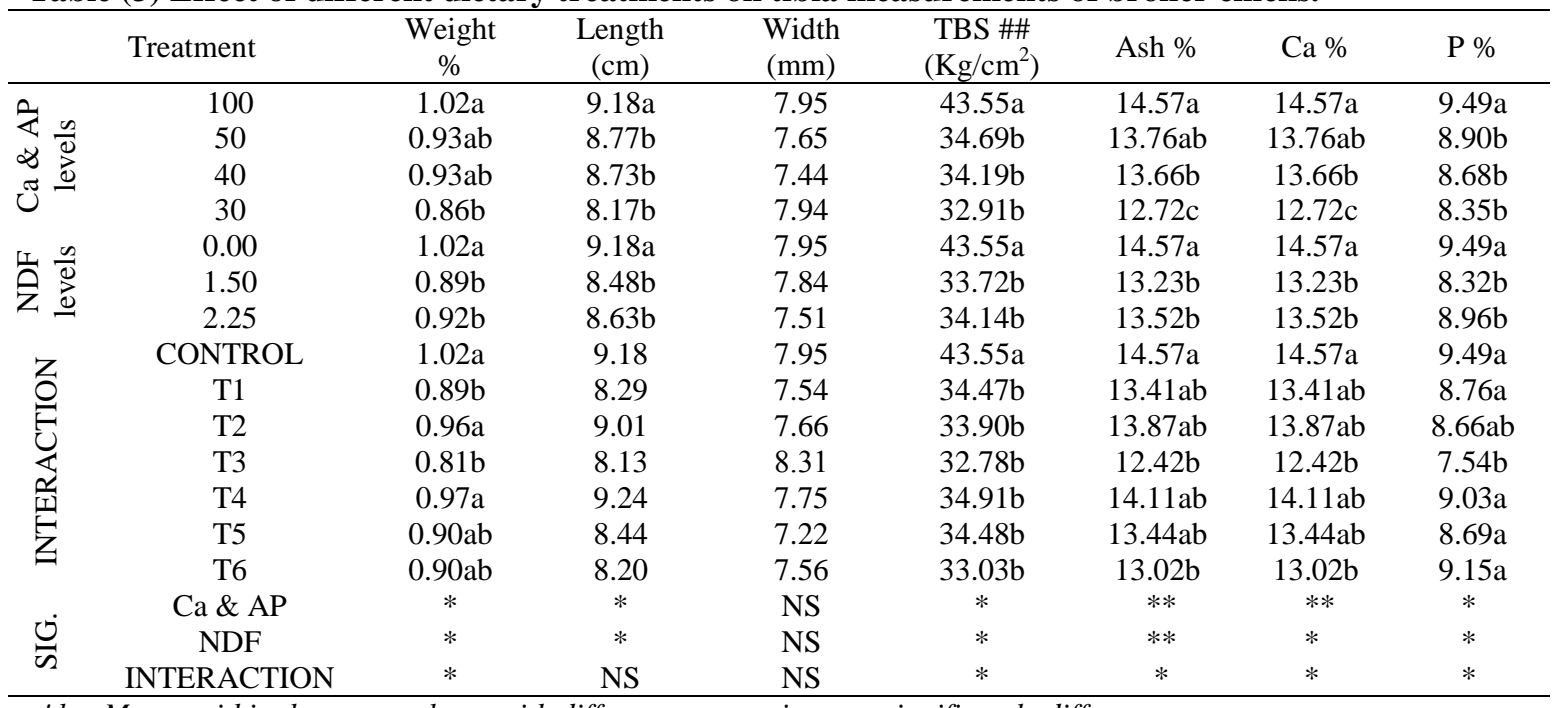

$a^{\prime} b c$ Means within the same column with different superscripts are significantly different.

Sig. $=$ Significance $* *(P<0.01), *(P<0.05) . N S=$ Non-Significant. - TBS $=$ Tibia breaking strength

\section{REFERENCES}

Abdelhady A.Y.M.; H.A. El-Alaily; S.A. Ibrahim and M.A.M. Abdelaziz (2015). Effect of Using Sodium Formate with Restricted Calcium and Phosphorus on Broiler Performance and Gut Health. Egyptian J. Nutrition and Feeds, 18 (2) 431-441

Adil, S., T. Banday; G. A. Bhat, M. S. Mir; and M. Rehman, (2011). Effect of Dietary Supplementation of Organic Acids on Performance, Intestinal Histomorphology, and Serum Biochemistry of Broiler Chicken. Vet Med Int. 479485.

AOAC (1995). Official methods of analysis. 16th ed. Association of Officials Analytical Chemists, Arlington, TX, USA

Boling, S. D., D. M. Webel; C. M. Parsons; and D. H. Baker, (2000). The effects of citric acid on phytate phosphorus utilization in young chicks. J. Anim. Sci. 78:682-689.

Bozkurt, M., K. Kucukyilmaz, A.U. Catli and M. Cinar (2009). The effect of single or combined dietary supplementation of prebiotics, organic acid and probiotics on performance and slaughter characteristics of broilers. Afr. J. Anim. Sci., 39: 197-204

Cherrington CA, M. Hinton, and I Chopra (1991). Short chain organic acids at pH 5.0 kill Escherichia coli and Salmonella spp. without causing membrane perturbation. J. of App. Microbiology 70, 161-165.

Damron, B.L. and L.K. Flunker, (1995). Calcium supplementation of hen drinking water. Poult. Sci. 74: 784-787.

Delezie, E., L. Maertens, and G. Huyghebaert. (2012). Consequences of phosphorus interactions with calcium, phytase, and cholecalciferol on zootechnical performance and mineral retention in broiler chickens. Poult. Sci. 91(10):2523-2531.

Dhandu, A.S. and R. Angel. (2003) Broiler nonphytin phosphorus requirements in the finisher and withdrawal phases of a commercial four-phase feeding system. Poult. Sci., 82: 1257-1265.

Dieckmann, A. (2004). Contributions to optimize the phosphorus supply of growing broilers. ed. (Gremany) 
Duncan D. B. (1955). Multiple range test and multiple F-tests. Biometrics; 11:1-42.

Esmaeilipour O, Aminzadeh S, Rezaian M, and M.M. Krimpen (2011) Effects of xylanase and citric acid on the performance, nutrient retention, and characteristics of gastrointestinal tract of broilers fed lowphosphorus wheat-based diets. Poult Sci 90:1975-1982

Flemming, R.H., L. Mctier and C.C. Whitehead. (1998). Medullary bone and humeral breaking strength in laying hens. Research in Veterinary Science, 64: 63-67.

García, V., P. Catala-Gregori, F.M. Hernandez, D. Megias and J. Madrid, (2007). Effect of formic acid and plant extracts on growth, nutrient digestibility, and intestine mucosa morphology and meat yield of broilers. J. Appl. Poult., 16: 555-562.

Günther, K. D. and M. R. Al-Masri, (1988). The influence of different phosphorus supply on phosphorus turnover in growing broiler chicks by means of isotope. J. of Animal Phys. and Animal Nutr. 59, 132142 .

Günther, K. D., Hermes, I. and H. Abel, (1978). The effect of phosphorus amount in the feed on phosphorus turnover in growing broiler chicks). 40, 13C-13 1.

Hebeler, D., Kulla, S., and G. Amtsberg, (2000) Influence of a formic acid-potassium formate complex on chyme composition as well as on the intestinal microflora of weaned piglets Proceedings of the Society of Nutrition Physiology 9: 63

Helen B. and L. Christian, (2010). Performance enhancement through the use of diformates in broiler. ADDCON company in Germany, Porsgrunn publication,

Hemme, A., M. Spark, P. Wolf, H. Paschertz, and J. Kamphues. (2005). Effects of different phosphorus sources in the diet on bone composition and stability (breaking strength) in broilers. J. Anim. Physiol. Anim. Nutr. 89:129-133.

Hermes, I. (1977). The utilization of phytin by growing broiler chicks, as influenced by total phosphorus and phytin phosphorus amounts in the feed). PhD Thesis, University of Gottingen, Germany.

Hernández F, García V, Madrid J, Orengo J, P Catalá, MD Megías. (2006). Effect of formic acid on performance, digestibility, intestinal histomorphology, and plasma metabolite levels of broiler chickens. Br Poult Sci; 47:50-56.

Islam K. M. S (2012). Use of citric acid in broiler diets. Worlds Poult Sci J; 68:104-118.

Izat, A.L., N.M. Tidwell, R.A. Thomas, M.A. Reiber, M.H. Adams, M. Colberg and P.W. Waldroup, (1990): Effects of a buffered propionic acid in diets on the performance of broiler chickens and on microflora of the intestine and carcass. Poult Sci. 69, 818-826.

Kheiri, F. and H.R. Rahmani (2006). The effect of reducing calcium and phosphorous on broiler performance. Intl. J.Poult.Sci.,5: 22-25.

Lückstädt C. and K. Wegletner (2012). The effective control of Salmonella in poultry by means of diformates. ADDCON Group GmbH, Bonn, Germany

Lückstädt, N. Greiffenstein and R. Dari (2014). Effect of dietary sodium diformate in broilers on the productivity index against a positive control. Conference on International Research on Food Security, Natural Resource. Organized by the Czech University of Life Sciences Prague

NRC (1994). National Research Council. Composition of poultry feedstuffs. National Academy of Sciences. Washington, D.C. USA.

Rafacz-Livingston K. A., Martinez-Amezcua C., D. H. Baker and J. Snow (2005). Citric acid improves phytate phosphorus utilization in crossbred and commercial broiler chicks. Poult. Sci.; 84:1370-1375. 


\section{Ibrahim et al.}

Rouhollah N., M. H. Seyed and F. Homayoun (2010). Influence of Citric Acid and Microbial Phytase on Growth Performance and Carcass Characteristics of Broiler Chickens. Am. J. of Animal and Vet. Sci. 5 (4): 282-288.

SAS (2002). Statistical Analysis System, SAS User's Guide: Statistics Ver. 6.04, 4th Ed., SAS Institute. Inc., Cary, NC. USA.

Schoner, F.-J., P. P. Hoppe, , G. Schwartz, and H. Wiesche, (1993). Comparison of microbial phytase and inorganic phosphate in chickens. The influence on performance data, mineral retention and dietary calcium. J. of Animal Phys. and Nutr. 69, 23 5-24,

Selle, P.H., Huang, K.H. and Muir, W.I. (2004). Effects of potassium diformate inclusion in broiler diets on growth performance and nutrient utilization. Proceed. Aust. Poult. Sci. Symposium: 55-58.

Snow, J. L., D. H. Baker, and C. M. Parsons. (2004). Phytase, citric acid, and 1 $\alpha$-hydroxycholecalciferol improve phytate phosphorus utilization in chicks fed a corn-soybean meal diet. Poult. Sci. 83:11871192.

Sohail, S.S. and S. Roland, (1999). Influence of supplemental phytase on performance of broilers four to six weeks of age. Poult. Sci., 78: 550-555

Summers, J.D., (1997). Precision phosphorus nutrition. J Appl. Poult. Res., 6: 495-500

Underwood, E.J. and N.F. Suttle, (2001). The Mineral Nutrition of Livestock, 3rd Edition. CABL publishing. pp 67-105

Van der Klis, J.D. and H.A.J. Versteegh. (1999) Phosphorus nutrition of poultry. In: Recent Developments in Poultry Nutrition. Nottingham University Press (UK), pp. 309-320

Waldroup P.W.; J.H. Kersey; Saleh E.A., C.A. Fritts; and V. Raboy (2000). Non-phytate phosphorus requirement and phosphorus excretion of broiler chicks fed diets composed of normal or high available phos-phorus corn with or without microbial phytase. Poult. Sci.79,1451-1459.

Wilson, S., and S. R. I. Duff. (1991). Effects of vitamin or mineral deficiency on the morphology of bone in laying hens. Res. Vet. Sci. 50:216-221.

Yan, F.; J.H. Kersey and P.W. Waldroup (2001). Phosphorus requirements of broiler chicks three to six weeks of age as influenced by phytase supplementation. Poult. Sci., 80:455-459 
تأثير المستويات المختلفة للكالسيوم والفوسفور المتاح وأملاح فورمات الصوديوم على 1- الأداء الإنتاجي وقياسات عظمة الساق لاجاج اللحم

سيد عبدالرحمن ابراهيم - حسين عبدالله العلايلي - مروان عبدالعزيز محمود عبدالعزيز- عبدالرحمن يوسف عمل عبدالهاديأحمد إبر اهيم سليمان الفحام

قسم إنتاج اللواجن- كلية النزراعة- جامعة عين شسم- القاهرة- مصر

أجريت تجربة للتعرف على نأثير إضافة مستويات مختلفة في أملاح فورمات الصوديوم إلى علائق منخفضة المحتوى من الكالسيوم

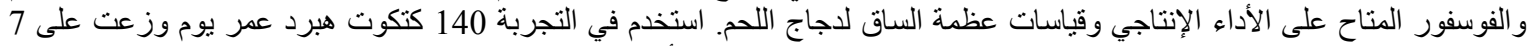

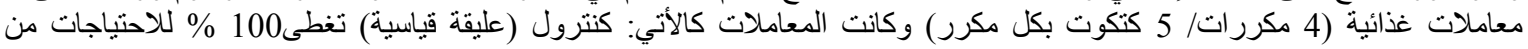
الكالسيوم و الفوسفور المتاح بدون إضافة فورمات الصورد

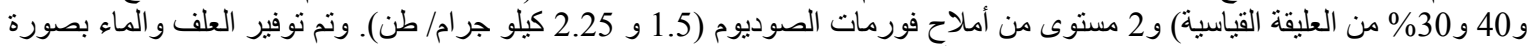
حرة للطيور طول الفترة التجريبية (35 يوم). و و كامنأهم النتائج:

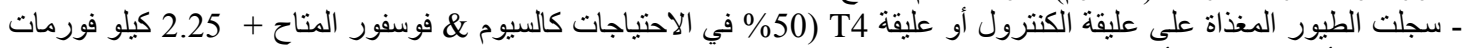
صوديوم / طن) أفضل نتائج للأداء الإنتاجي (وزن الجسم والوزن الككتسب واستهلاك العلفومعامل تحويل غذائي) بالمقارنة بالمعاملات الأخرى. - إن.

- سجلت الطيور المغذاه على عليقة الكنترول أو عليقة T4 أفضل نتائج لقياسات عظمة الساق (طول وسمك عظمة الساق) و التركيب

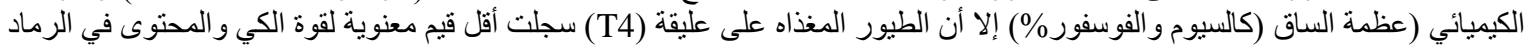

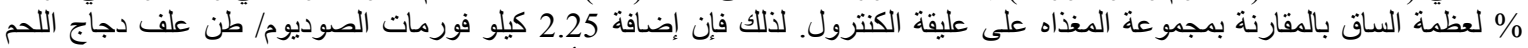
المنخف في المحتور في الكالسيوم و الفوسفور المتاح (50\%) عن الاحتياجات يحسن الأداء الإنتاجي ومعظم قياسات عظمة الساق. 